\title{
The Rhetoric and Realities of Labour Market Reforms
}

\author{
(C) Dr. Vidyadhar Ishwar Badigannavar \\ Aston University, UK
}

Citation: Badigannavar, Vidu. (2021). The Rhetoric and Realities of Labor Market

Reforms. SSRN Electronic Journal. 10.2139/ssrn.3845757.

The recent reforms to labour laws in India have created a very polarized debate among key stakeholders and policy analysts. The government's position is that the myriad labour laws in India create complexity and poor employer compliance. Hence the need for simplification. Moreover, simplification of labour laws would facilitate the ease of doing business and consequently attract private domestic and foreign capital into India. This capital inflow will in turn boost employment in the country. Thus, labour law reforms become a part of wider stimulus package for economic revival. Trade unions on the other hand have opposed labour law reforms as they fear it erodes employment security, the right to collective representation and ability to undertake legal strikes. This raises two fundamental questions. First, how unique are the labour law reforms in India or have other countries embarked on similar pathways to revive their economies? Second, what has been the economic impact and labour market outcomes of such reforms in countries where governments have introduced labour law reforms? In addition to these questions, there is an ideological issue that needs addressing at the outset. Do only 'right-wing' political parties de-regulate labour markets? In this article, I wish to contextualise labour market reforms in India in an international perspective which is often missing in the rather insular and inward-looking debate on labour reforms in India.

\section{The Right versus Left-wing political debate on labour reforms:}

1990 witnessed the reunification of the East Germany (German Democratic Republic) with the West Germany (Federal Republic of Germany) to form a unified Germany. What the unified Germany inherited from the GDR was large scale unemployment and a treasury bereft of funds. The reunification was a major macroeconomic shock for Germany which witnessed soaring unemployment and economic crisis. In 1998 the Socialist Democratic Party (SPD) and the Green Party came to power forming a coalition of two left-wing parties in government. Under the leadership of Chancellor Gerhard Schroeder of the SPD Germany introduced the most radical labour market reforms drastically reducing the job security provisions for 'atypical workers' which includes, temporary, contract, casual workers, apprentices/trainees and migrant workers along with cuts in unemployment 
benefits to 'encourage people to seek work'. This de-regulation of employment security laws was to enable firms to flexibly hire and fire employees and thereby better match their internal demand and supply of labour with their business needs (Patterson and Sloam 2006; Behrens 2020). These reforms to job security provisions have continued to the present day with the Socialist Democratic Party still in power (at the time of writing this article) in coalition with the Christian Democrats. Besides Germany, other social democratic countries such as Sweden, Belgium and Denmark too have reduced employment security provisions for temporary contract workers since the 1990s.

\section{OECD- Strictness of Employment Protection Laws for Regular and Temporary Contracts}

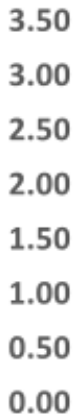

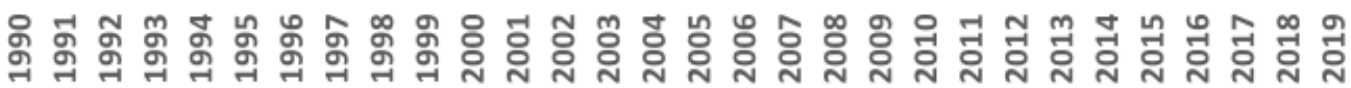

-Germany regular contracts -UK Regular contracts

- Germany Temporary contracts - UK Temporary contracts 


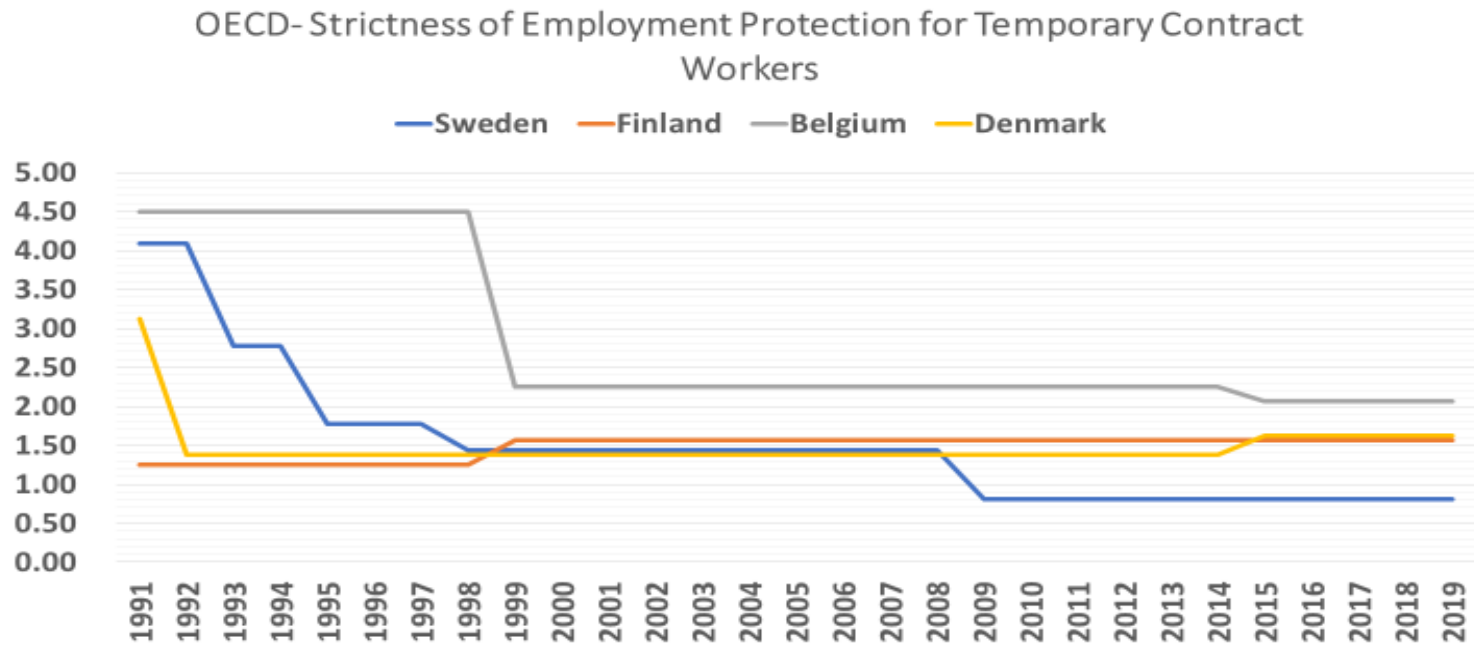

Source: OECD Stats.

The Labour Party in Britain was formed by the trade unions. Labour came to power in the UK with a landslide majority in the 1997 General Elections under the leadership of Tony Blair. The party remained in power for 13 years since 1997 up until 2010. During this reign the party did not overturn a single anti-union law passed by its predecessor Conservative Government of PM Margaret Thatcher. Governing with a parliamentary majority, the Labour Party could have overturned the anti-union laws, but they chose not to (Smith and Morton 2006). During its term in office, the Labour Party embarked on an aggressive privatisation agenda with government funded 'failing schools' being handed over to private companies, public hospitals, services and infrastructure projects being commissioned under the 'Public Private Partnerships', introduction of tuition fees for university students and deregulating the financial sector to an extent that contributed hugely to sub-prime lending, derivatives scandals and the 2008 global financial crisis resulting in large scale unemployment and financial hardships to the most vulnerable sections of the society (Clarke, Newman and Westmarland 2008).

In 2014, the left-wing Socialist Party government in Bolivia under the leadership of President Evo Morales legalised child labour in the country from the age of 10 years. A 10year-old working child in Bolivia is now officially classified as a 'self-employed' person. From the age of 12 years a child can be legally employed by a third-party employer. Ostensibly this was a poverty alleviation programme of the Socialist Party (Simpson 2014; 
Liebel 2015). In the People's Republic of China, the largest communist country in the world, all independent trade unions are banned. All unions have to be affiliated to the All China Federation of Trade Unions (ACFTU) which is not independent and remains a mouthpiece of the Chinese Communist Party (Liu 2020). In 2020, the Chinese government passed the National Security Law for Hong Kong. The law prohibits all forms of pro-democracy protests including labour protests which are classified as anti-national activities leading to imprisonment (ITUC 2020). Thus, the argument that only 'right-wing' governments enact anti-labour reforms is problematic and misleading.

\section{Economic and Employment Outcomes of Labour Market Reforms:}

In this section, I will examine the economic outcomes of labour reforms in two major European economies i.e. Germany and the UK - both of which have seen weakening of job security provisions and collective bargaining rights over the past 30 years.

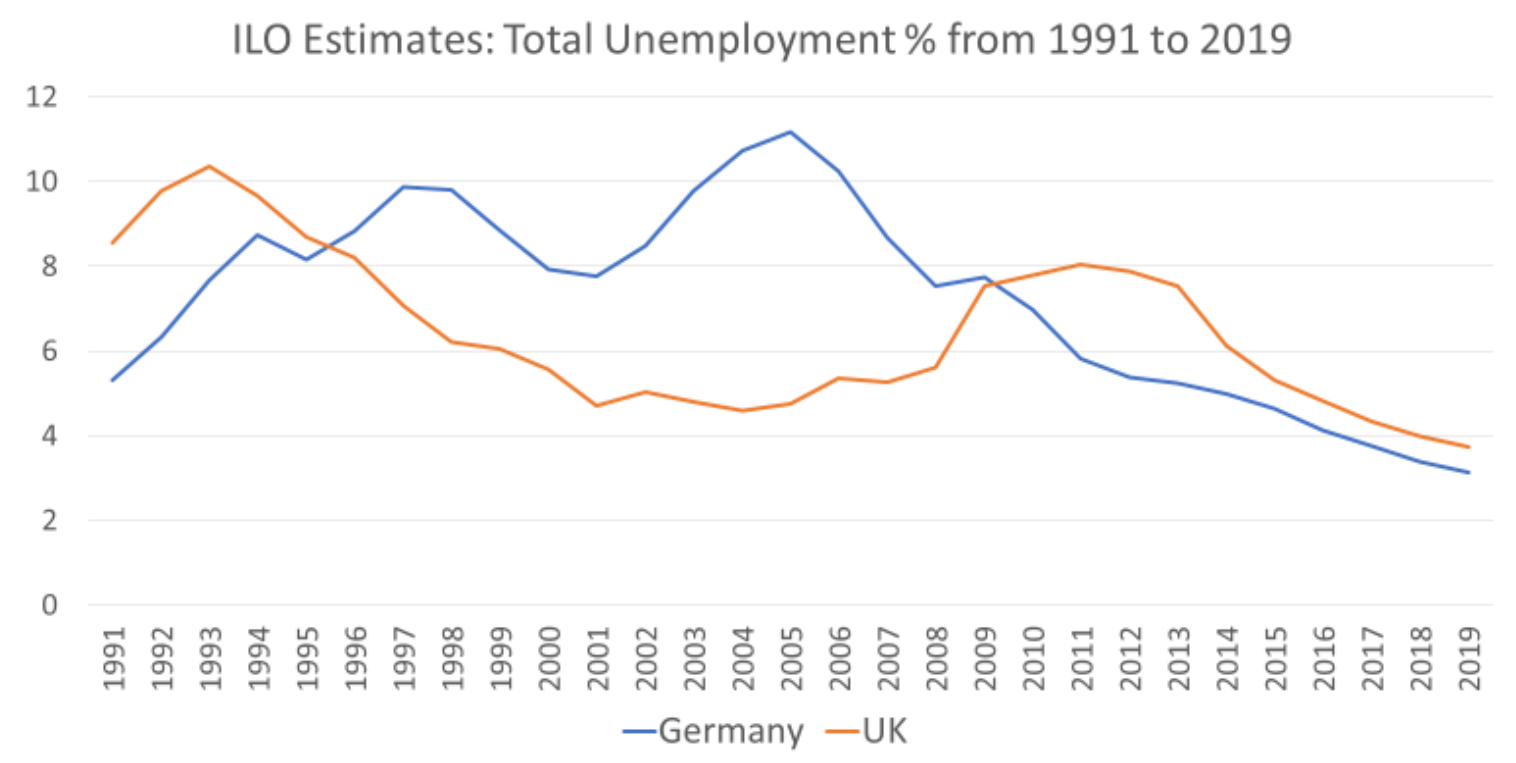

Source: ILO Stats.

The figure above illustrates total unemployment levels in Germany and UK from 1991 to 2019. Unemployment had peaked in Germany in around 2005 but subsequently, witnessed a steady fall in unemployment until 2019. Even during the 2008-2012 global financial crisis, total unemployment remained low which in case of UK had risen to around $8 \%$. Following the labour law reforms in the UK in 1990s, total unemployment fell sharply from around $10 \%$ to about $4.5 \%$ in early 2000 s and remained low until the global financial crisis. During the economic recovery period from 2012-13, UK unemployment continued to fall despite 
further dilution to job security provisions for all types of employees by the UK government in 2012. It probably reflects greater confidence on part of firms to recruit workers knowing that they could adjust their internal labour markets in response to business needs.

We also need to examine the type of employment being created in the UK and Germany post labour market reforms, particularly for the young workers who are entering the labour market.

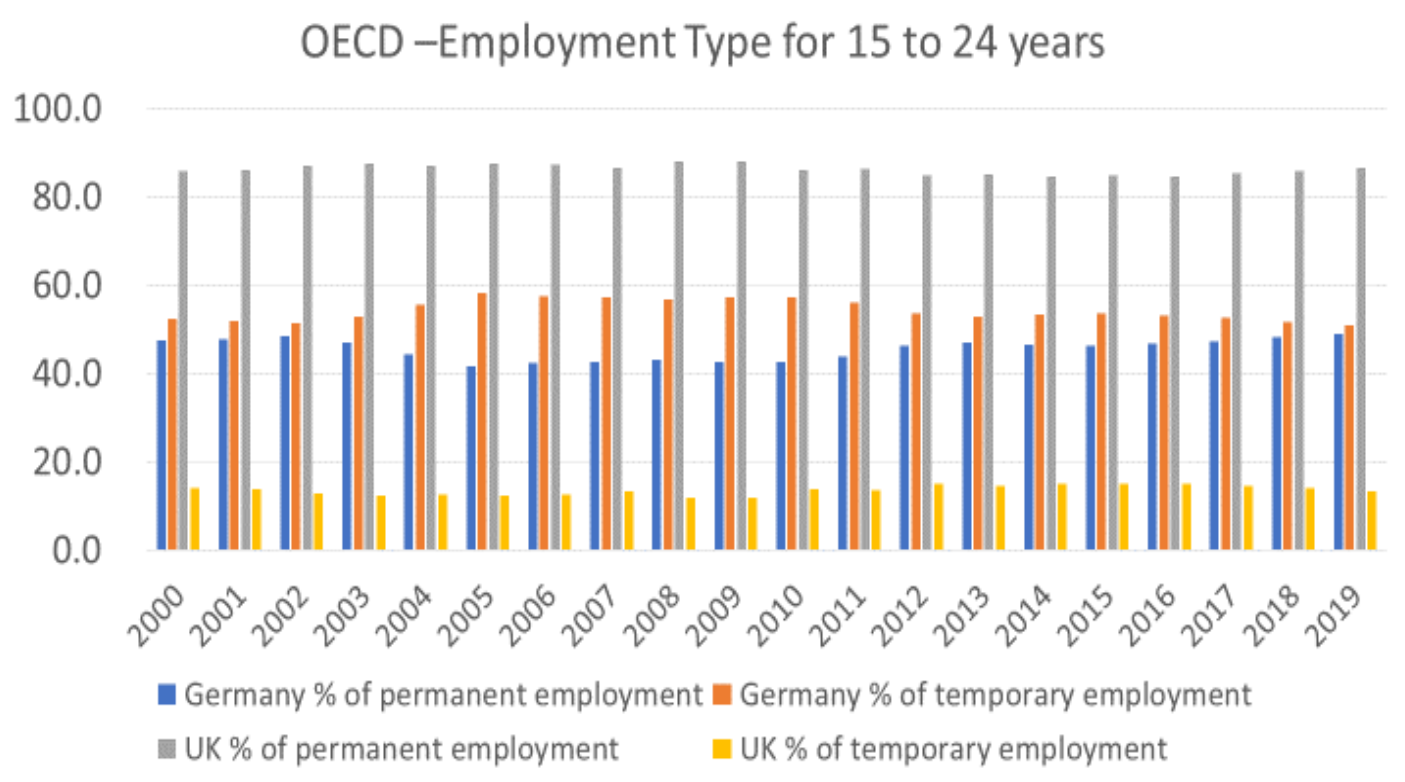

Source: OECD Stats.

OECD employment figures for Germany from 2000 to 2019 show a rise in the proportion of temporary workers aged 15 to 24 years from about $50 \%$ to $59 \%$ from 2000 to 2005 while those on permanent contracts declined from about $45 \%$ to $41 \%$ over the same time period. In the UK however, the proportion of temporary workers aged 15 to 24 years have remained largely the same at about $10-12 \%$ over a 20 year period. In Germany, the gap between proportion of temporary and permanent workers has narrowed since 2012 and has virtually closed by 2019. A large majority (about 80\%) of young workers in the UK have been employed on permanent contracts regardless of the macroeconomic conditions or the weakening of job security provisions. 
Trade union density on the other hand has declined in both the UK and Germany but this decline cannot be solely attributed to the de-regulation of labour markets.

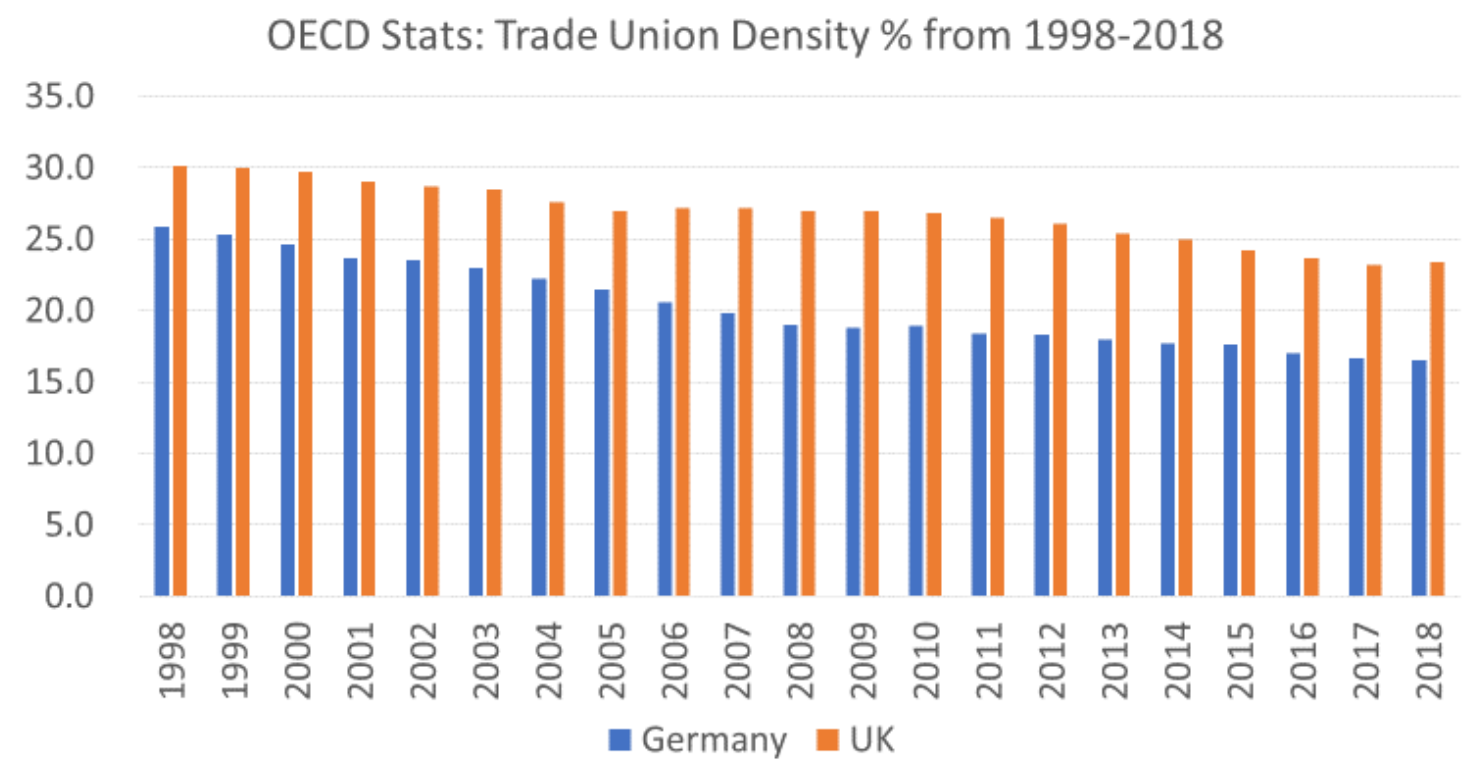

\section{Source: OECD Stats.}

German trade union density declined from around $26 \%$ in 1998 to about $16 \%$ in 2018 while the UK witnessed a fall in union density from 30\% in 1998 to $23 \%$ in 2018. Most analysts would attribute the fall in union density in both countries to a combination of factors including labour law reforms, structural changes in the economy i.e. a decline of manufacturing, shrinking of the public sector and failure of unions to actively recruit workers in the growing private service sectors (Kelly 2020; Behrens 2020).

The overall health of the German and UK economies however looks robust following the labour market reforms. The World Bank estimates show a consistent rise in the Gross Value Added (GVA) in the two economies from 1991 up until 2019 with a dip in between during the global financial crisis. On the whole Germany has outperformed UK on the GVA indicator and has shown better performance even during the 2008-12 financial crisis. 


\section{World Bank: Gross Value Added (GVA) 1991 to 2019}

$4 E+12$

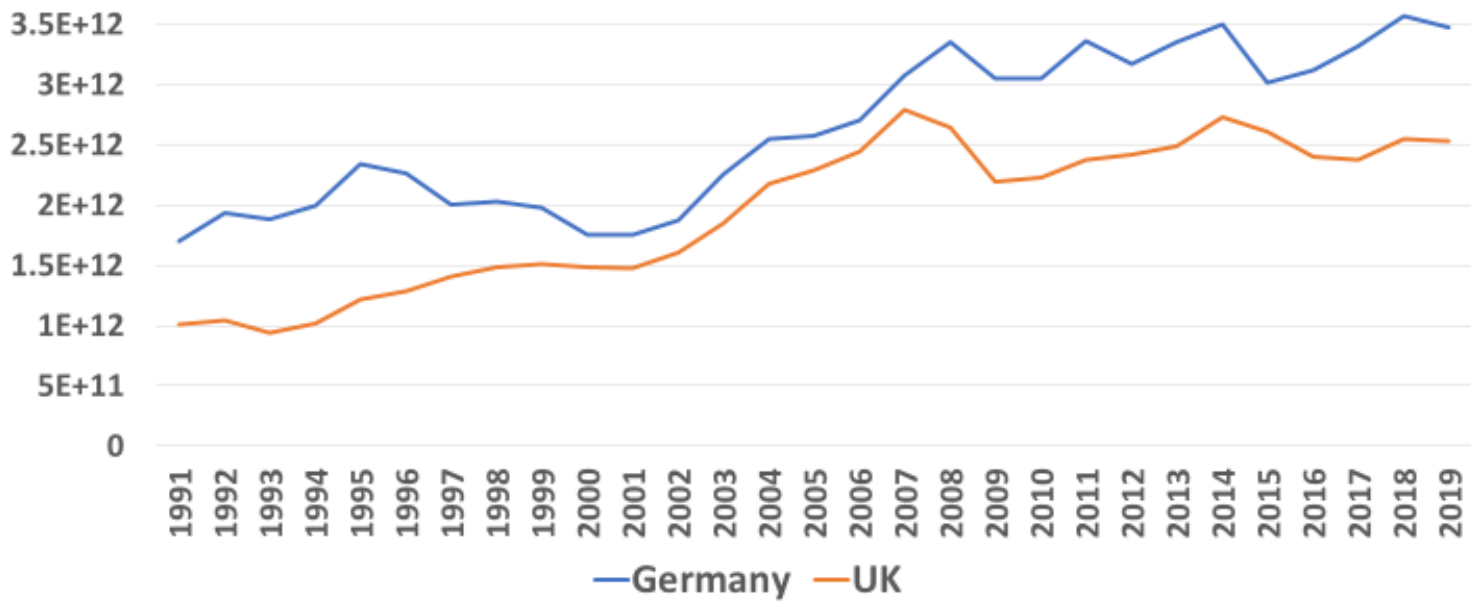

World Bank - GDP Per Capita in US\$ from 1991 to 2019

60000

50000

40000

30000

20000

10000

0

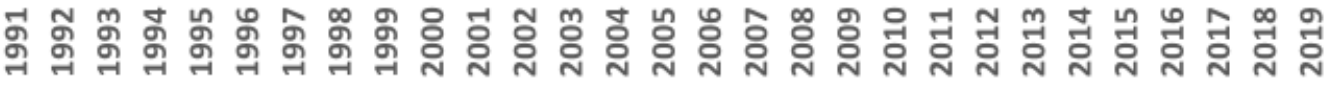
-Germany -UK

Source: World Bank Stats.

The GDP per capita for both Germany and UK also show a rising trend from 1991 to 2019.

While per capita GDP is a crude indicator of the material wellbeing of the country's population, it nevertheless is often used to assess the overall economic performance of a 
nation alongside its GDP. Several factors may contribute towards GDP per capita but the point here is that job security legislative reforms in the two countries are associated with a fall in total unemployment and thus are likely to have facilitated the economic growth in the two countries. While the GVA and GDP per capita may be an indication of the overall health of the economy, we also need to see how workers have fared in the growing economy.

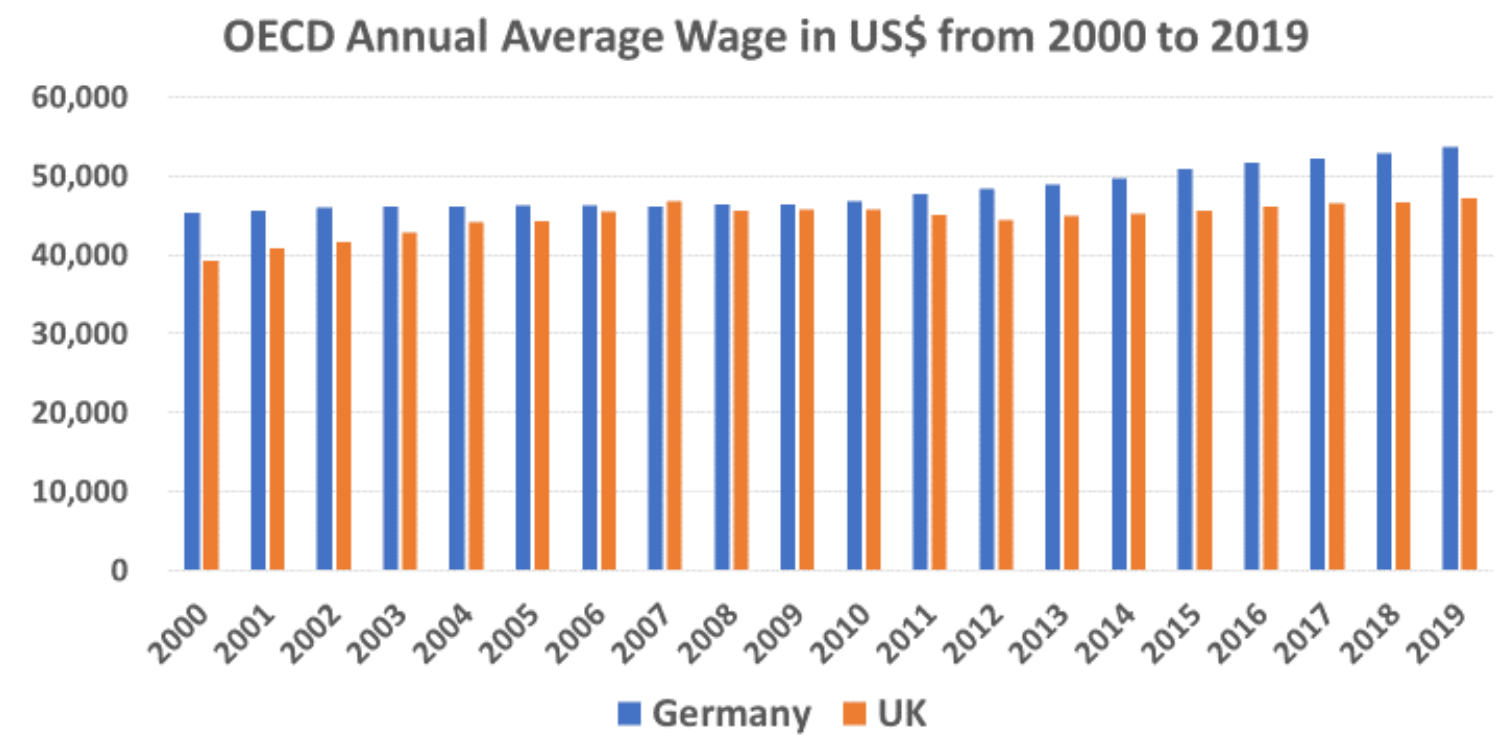

Source: OECD Stats.

OECD data on annual average wage in US\$ shows that in both countries annual average wages of workers have risen consistently from 2000 to 2019. Here again, workers in Germany have done better compared to those in the UK. Average annual wages have remained stable or have slightly risen even during the global financial crisis of 2008-12. One could argue that average annual wages while useful do not accurately reflect the earnings of workers at the lowest end of the economic ladder - often those who are employed on the statutory minimum wage. The UK introduced a National Minimum Wage law in April 1999 while Germany introduced it in January 2015. 
OECD: Real Minimum Wage in US\$

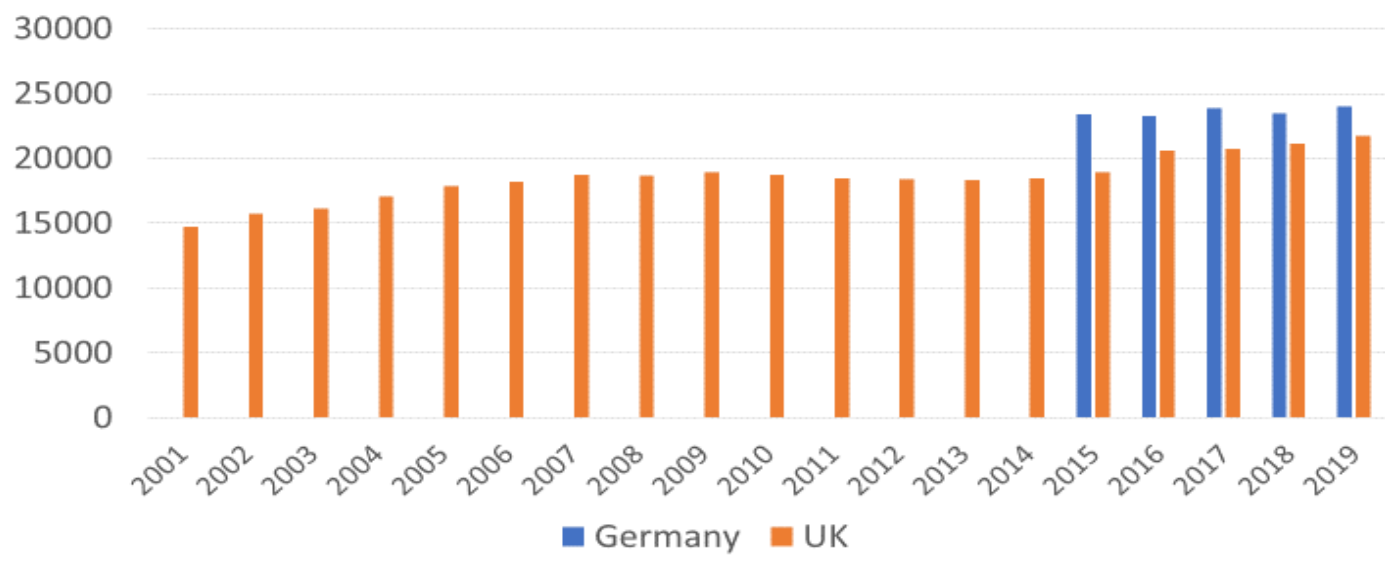

Germany introduced National Minimum Wage in 2015

Source: OECD Stats.

The real minimum wage (after controlling for price inflation) of workers in the UK and Germany have steadily risen in both countries. In the UK there was a marginal drop in the real minimum wage from 2010 to 2014 but since then it has recovered and has increased from 2015 to 2019 . What these figures show is that even the most vulnerable sections of the workforce employed on minimum wages have not suffered any significant wage loss as a result of labour market reforms introduced by these two countries over the past 3 decades. Both, average annual wage of workers and the real minimum wages show a healthy trajectory alongside falling total unemployment.

I finally look at the Social Spending as a percentage of GDP in the UK and Germany over a 20-year period from 2000 to 2019 . The social spending largely refers to government spending on public education, public health care, unemployment support, child benefits and state pension. 


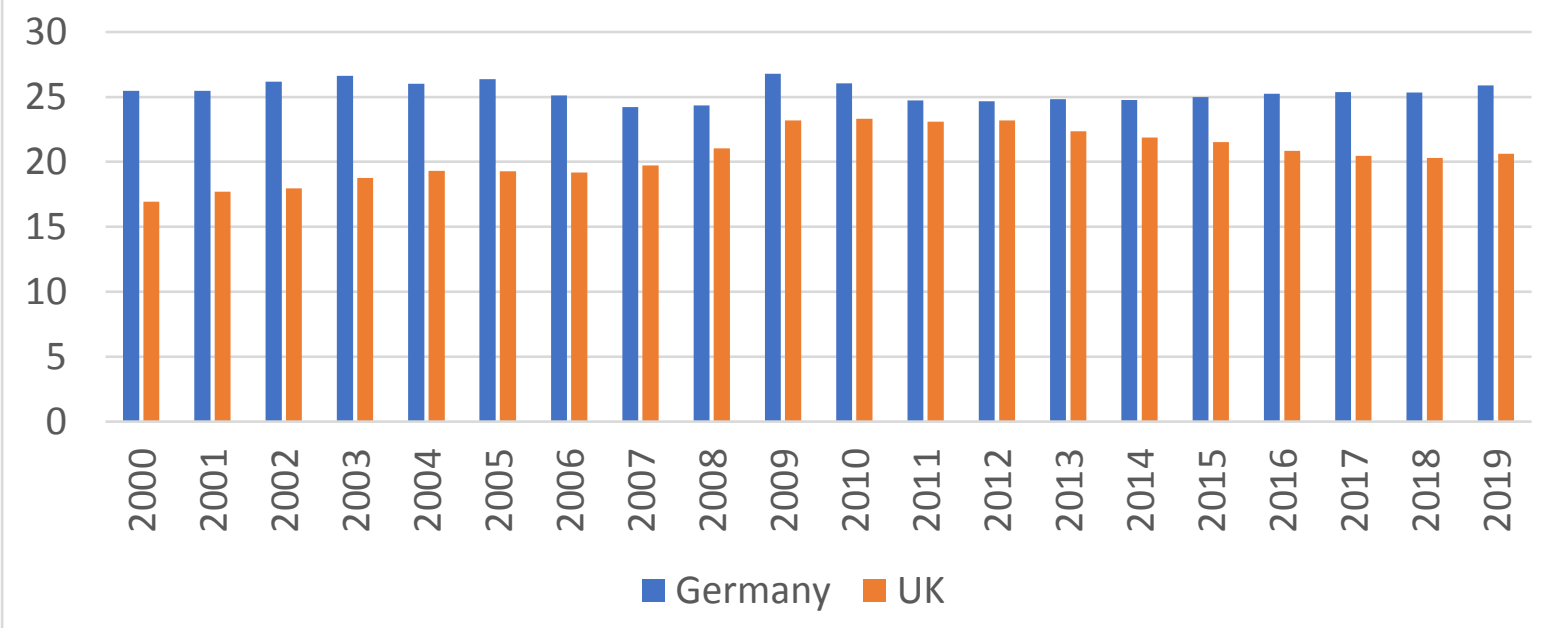

Source: OECD Stats.

OECD figures indicate that the social spending in Germany has remained at about $25 \%$ of the GDP from 2000 to 2019 , while the social spending in the UK increased from about $17 \%$ in year 2000 to $24 \%$ of the GDP in 2010 . It then steadily declined with the austerity measures implemented by the Conservative-Liberal Democrat coalition govt that came to power in 2010. In 2019, under the Conservative party rule, UK spent just over $20 \%$ of its GDP on social welfare. Similarly, Sweden and Belgium who also de-regulated their labour markets since the 1990s, have a generous welfare state in place with social spending in Belgium at $28.90 \%$ of its GDP in 2019 and the corresponding figure for Sweden being $25.45 \%$.

Key observations on labour reforms and economic recovery in Germany and the UK:

Both countries introduced what may be described as anti-worker and anti-union labour reforms in the 1990s particularly targeting job security provisions in employment laws and privatization of public services. It is worth noting that left-wing ideologies of the ruling parties did not stop them from introducing harsh labour market reforms in Germany or continuing with anti-labour laws introduced by their predecessors in the UK. Social Democratic governments of Scandinavian countries such as Belgium, Denmark and Sweden too introduced similar labour law reforms in the 1990s and early 2000s. Following these reforms, the total unemployment in Germany and UK reduced substantially and has continued to remain low. The weakening of job security provisions for temporary and atypical workers appears to have increased the proportion of young workers aged 15-24 years employed on temporary contracts in Germany. However, this trend has subsequently 
declined and by 2019 the proportion of young workers employed on permanent and temporary contracts were about the same. UK has never seen a substantial rise in the employment of young workers on temporary contracts with figures hovering around 10 to $12 \%$ of 15 to 24 -year olds on temporary contracts from 2000 to 2019 . About $80 \%$ of young British workers were employed on permanent contracts during this period.

Trade union density in both Germany and UK have declined from 1998 to 2018 but this decline cannot be solely attributed to changes in labour laws. Structural changes in the economy and inability of unions to organise and recruit younger workers in the growing private services sector has contributed to their declining fortunes. We have witnessed steady economic growth in Germany and the UK following labour market reforms. This is evidenced in the growth in per capita GDP and the Gross Value Added to the economy from 1991 to 2019. Workers appear to have benefited from this economic growth. Annual average wage in both countries has increased from 2000 to 2019 and, the real minimum wage too has shown a rising trajectory. Social spending as a percentage of GDP has been high in Germany and reasonably generous in the UK compared to many other developed economies. Thus, on the whole labour law reforms appears to have stimulated economic recovery in both countries. The welfare state provides a safety net to workers in a deregulated labour market.

\section{Implications for India:}

It is difficult to make direct comparisons between India and Western economies such as Germany or the UK. Nevertheless, some analytical cross-references may be helpful. The Indian labour law framework was largely inherited from the British colonial rule and the report of the Second National Commission on Labour (SNCL 2002) appointed by the Indian government has similarities with the Fairness at Work (1998) policy of the Labour Government in Britain. The recent Labour Codes and in particular the Code on Industrial Relations draws upon the recommendations of the SNCL. The Indian governments industrial strategy since 2014 aims at promoting the manufacturing sector in the country and it has entered into several bilateral agreements with the governments of UK and Germany in areas of education, skill training and manufacturing. The historical context of labour laws in India and the government's contemporary policies offer some basis to draw analytical cross-references. 
Labour market reforms are not an entirely a new phenomenon in India. Labour being a concurrent subject, both federal states and the central government have historically legislated on issues of labour law and labour welfare. Several states in the past have amended the statutory provisions of the Industrial Disputes Act (IDA) 1947 in either proworker or pro-employer directions. Beasley and Burgess (2004) analysed these amendments to the IDA over a 34 year period from 1958 to 1992 and found that states which had amended the IDA in a pro-worker direction reported lower industrial output, employment, investment and productivity in the registered manufacturing sector while at the same time increasing output in the unregistered or informal manufacturing sector. Pro-worker changes to the IDA were also associated with a rise in urban poverty. The authors concluded that states which tried to redress the power imbalance between capital and labour by amending the IDA in a pro-worker direction were inadvertently causing more harm to the poor. Beasley and Burgess's work was criticised largely on their use of empirical methods but recent work by Chakraborty (2021) which overcomes some of the econometric limitations of Beasley and Burgess also concludes that stringent labour regulations adversely affect employment in the manufacturing sector. Chakraborty speculates that stringent labour regulations exacerbates sub-contracting of production in the manufacturing sector. This in turn results in larger proportion of workers being employed in the informal sector where there is a serious decent work deficit. He recommends labour market reforms as a policy albeit with a caveat that state should also invest in social welfare.

My analysis of labour market reforms in Germany and the UK and those in the Scandinavian countries since the early 1990s, also supports the view that such reforms stimulate economic recovery, reduce total unemployment and improve the earnings of workers in the labour market. The evidence does not indicate a wholesale casualisation of the labour market. Germany and UK as also the Scandinavian countries like Denmark, Belgium and Sweden have strong welfare states supported through higher percentage of GDP being spent on social support such as public health care, education, skill development, unemployment support, child benefit and state pension. India in comparison spends far less on social welfare. In 2019, India spent a mere $7.7 \%$ of its GDP on social welfare. Social welfare is often supported through government's income tax and corporate tax revenues. However, state can only tax the income of individuals earning above a certain threshold. Low wage economies do not generate high tax revenues through personal income tax. Likewise, states can only tax corporations if they are financially viable and profitable. India has serious issues with tax compliance by individual taxpayers and corporate entities. 
Populist political policies on taxation do not help the situation either. This needs to be addressed in order to increase the revenue available for social spending.

It is often said that India has a large informal economy comprising of enterprises which are unregulated and workers in those enterprises who fall outside the scope of labour laws and welfare system. There is evidence of informalisation of work within the formal enterprises by virtue of sub-contracting and hiring of casual or temporary workers. Trade unions need to actively organise and address the issues of contract and temporary workers as they have increasingly done in many parts of the world. It is ironical that according to the official figures of the National Sample Survey, in 2012, there were $27 \%$ of temporary and casual workers employed in enterprises with a union presence but the contract workers were not members of that union. In-fill recruitment of these contract workers in enterprises with recognised unions would help bolster union membership and offer protection to vulnerable groups of workers. Indian trade unions have been campaigning for social security protection for informal sector workers and in particular migrant workers. These campaigns are a step in the right direction and unions should advocate social security for all with universal coverage and not just for those currently employed in the labour market. Formalisation of employment through universal access to social security (particularly investment in skill development, public health and pensions) must be the priority for all stakeholders.

Ideological rhetoric and wholesale opposition to labour reforms may risk economic recovery and further harm the poor.

Historically, union membership growth has been associated with economic growth and not with economic downturns or, business closures (Metcalf 2005). Public sector employment has and continues to shrink in most parts of the world. It would be prudent for the labour movement in India to take a leaf out of the strategies of several European trade unions in engaging with businesses and governments as pragmatic partners rather than perpetual adversaries. The Global Deal for Decent Work Report (2020) by the ILO and OECD illustrates how social dialogue between unions, governments and employers can help countries cope with the economic challenges of the COVID-19 pandemic. Labour market reforms in conjunction with social welfare policies can stimulate economic recovery, job creation and better wages.

\section{References:}

Beasley, T., \& Burgess, R. (2004). Can labour regulation hinder economic performance? Evidence from India. Quarterly Journal of Economics, 119(1), 91-134 
Behrens, Martin. (2020) 'Employment Relations in National Context: Germany' in Frege, C. and Kelly, J (eds) Comparative Employment Relations in the Global Context, Routledge, London and New York.

Chakraborty, S. (2021) 'Labour Market Regulations and Manufacturing Employment: A Study of Organized Manufacturing Sector Across Indian States' The Indian Journal of Labour Economics, (64): 1-22.

Clarke, John; Newman, Janet and Westmarland, Louise (2008) 'The antagonisms of choice: New Labour and the reform of public services.' Social Policy and Society, 7(2) pp. 245-253.

ILO (2020) 'The Global Deal for Decent Work and Inclusive Growth Flagship Report' https://www.ilo.org/global/publications/books/WCMS_758550/lang--en/index.htm

ILO Stat: https://ilostat.ilo.org/

ITUC (2020): Council of Global Unions Joint Solidarity Statement - Justice for Lee Cheuk Yan and ensuring fundamental rights in Hong Kong

https://www.ituc-csi.org/council-of-global-unions-joint

Kelly, J. (2020) 'Employment Relations in National Context: UK' in Frege, C and Kelly, J. (eds) Comparative Employment Relations in the Global Economy, Routledge, London and New York.

Liebel, M (2015) 'Protecting the Rights of Working Children instead of Banning Child Labour', International Journal of Children's Rights vol.23: 529-547.

Liu, M (2020) 'Employment Relations in National Context: China' in Frege, C. and Kelly, J.(eds) Comparative Employment Relations in the Global Economy, Routledge, London and New York.

Metcalf, D. (2005) 'Trade unions: resurgence or perdition? An economic analysis' in Fernie Susan and David Metcalf (eds.) Trade Unions: Resurgence or demise, Routledge, London and New York.

Organization for Economic Co-operation and Development OECD.Stat: https://stats.oecd.org/

Paterson, W. and Sloam, J. (2006) 'Is the left alright? The SPD and the renewal of European social democracy', German Politics, 15:3, 233-248, DOI: 10.1080/09644000600877735 
Simpson, J. (2014) 'Bolivia becomes first nation to legalise child labour' The Independent, Sunday 20 July 2014. https://www.independent.co.uk/news/world/americas/bolivia-becomes-first-nationlegalise-child-labour-9616682.html

Smith Paul and Morton Garry (2006) 'Nine Years of New Labour: Neoliberalism and Workers' Rights’ British Journal of Industrial Relations, 44(3): 401-420

World Bank Statistical Performance Indicators: https://www.worldbank.org/en/programs/statisticalperformance-indicators

\section{About the Author:}

Dr. Vidyadhar Badigannavar holds an MSc with Distinction and PhD from the London School of Economics (LSE). He is a labour economist and Associate Professor (Senior Lecturer) in Work and Organization at Aston University, UK. He has extensive research and consultancy experience in the UK, Europe, South and SE Asia, Middle-East and Africa. He has published widely on employment relations in leading journals such as the British Journal of Industrial Relations, Advances in Industrial and Labor Relations, Economic and Industrial Democracy, International Labour Review and the International Journal of Human Resource Management. 